by the Constitution Revision Commission whose mandate was extended for one more year by the Board. The Commission was set up in 1970 to prepare the draft texts on which the extraordinary session worked. As in the case of the Constitution the Commission will draw extensively on proposals from National Societies in drafting the new Rules.

\title{
INTERNATIONAL RED CROSS MUSEUM AT CASTIGLIONE
}

The Steering Committee of the International Red Cross Museum held its annual meeting at Castiglione on 11 March. The Italian Red Cross was represented by the Presidents of the local committees of Mantua, Verona, Milan, Brescia and Castiglione.

The Committee adopted after consideration a new set of rules for the running of the Museum. These rules do not affect the Museum statutes, but do bring them into line with the regulations of museums in Lombardy in general. The Committee approved the report for 1976 drawn up by Mr. Mutti, the Museum Director, and giving in the main an account of the exhibition organized by the ICRC in that year. The Committee also approved the Museum's accounts for the financial year.

Following the recent death of the Committee President, Mr. Emilio Ondei of Brescia was elected as the new President. Mr. Boletti continues as one of the two vice-presidents and Mr. Pierre Gaillard of the ICRC was elected as the second vice-president in place of Mr. Marc Gazay, who has announced his forthcoming departure from the League. The new League representative on the Committee will be Mr. Murdoch, Director of the League Information Bureau, and the representative for the Henry-Dunant Institute will be Mr. Akerhielm.

For 1978, the 150th anniversary of Henry Dunant's birth, the Museum will organize a special event at Castiglione. 